\title{
Weight, Density and Space in the Norwegian Reindeer Crisis-Notes Towards a Critique
}

\author{
Hugo Reinert
}

\begin{abstract}
For decades now, the dominant narrative about indigenous reindeer pastoralism in northern Norway has been that there is a crisis of excess: an oversized reindeer population, poorly held in check by poorly governed herders, is overgrazing the tundra, degrading the pasture grounds, spilling over into urban spaces and precipitating moral crises by starving to death "out there," on the tundra. Set against the background of this ongoing crisis, the present paper focuses on a set of particularly dense conceptual intersections that cluster around the notion of weight, and the manner in which weight functions both as a crisis indicator and a metric for assessment in contemporary Norwegian pastoral governance. Tracing the work and structure of the weight concept as applied to reindeer-against a dominant government narrative that parses numerical indicators as neutral, objective and apolitical - the paper outlines some of the erasures that the weight metric simultaneously carries out and occludes. The aim of the exercise is to specify and critically reframe certain core issues in the current management of Norwegian pastoralism, by problematising the supposedly neutral, scientific operation of quantitative metrics and assessment practices.
\end{abstract}

Key words: crisis; reindeer; pastoralism; space; indicators; assessment

Reindeer pastoralism is one of the key livelihoods of the indigenous Sámi population in northern Norway. Within the designated Sámi reindeer herding area, which extends from Roros in the south to the Russian border at Kirkenes in the north, reindeer are privately owned,

Hugo Reinert, Estonian Institute of Humanities, Tallinn University, and Noragric, Norwegian University of Life Sciences, hugo@tlu.ee

(C) 2014 Hugo Reinert

LiU Electronic Press, DOI 10.3384/vs.2001-5992.1422153

http://valuationstudies.liu.se 


\section{Valuation Studies}

migrating between seasonal pastures under the supervision of herders, and are slaughtered primarily for meat (Reinert 2008). The practice is centuries old, quite possibly more, but has undergone tumultuous shifts over the last few decades: demographic and socioeconomic change, the advent of motorisation, orientation towards new markets, integration in the national infrastructure and, not least, a dramatic escalation in State involvement-particularly since the late 1970s, with the Reindeer Herding Act of 1978 and the first Reindeer Herding Agreement in 1976, both of which were pivotal junctures in Norwegian State-Sámi relations. Presently, there is a near-universal consensus among industry stakeholders-including politicians, government officials, biologists, journalists and many in the reindeer herding community itself-that Norwegian reindeer herding is in crisis. This crisis discourse circles primarily around the notion of a reindeer excess in the core herding areas of Finnmark, the northernmost district in Norway. The tale varies but depending on the teller, supernumerary reindeer populations threaten to graze down pasture areas to the point of desertification, alter and degrade local ecosystems, diminish biodiversity, invade urban space, generate suboptimal meat outputs, inconvenience other stakeholders and, ultimately, starve to death on the tundra, causing a national crisis of animal welfare. To prevent this, reindeer populations need to be reduced. This has been the "official" government line for decades, more or less independently of party politics-and traceable, some argue, as far back as the mid-nineteenth century (Bjørklund 1999a; 1999b; Strøm-Bull et al. 2001).

This ongoing crisis is a highly complex entity, a massive but diffuse juncture that functions as something of a "boundary object" (Star and Griesemer 1989)—forging links and a sense of shared agreement across a broad cross-sectional coalition of actors, disciplines, political positions and communities of discourse. Its circulation as a social reality depends simultaneously on an almost instantaneous, commonsensical apprehensibility— "everybody knows" there are too many reindeer in Finnmark - and on its consolidation and elaboration through the media, by political actors and in the expert technical discourse of a relatively small community of government-funded scientists, primarily biologists. Arguments concerning the nature, extent, causes and possible solutions of the crisis are extensive, and have been ongoing for decades (see e.g. Paine 1992; Bjørklund 1999a; Hausner et al. 2011; Benjaminsen, Reinert, et al., forthcoming). A full account would need to unravel its combination of transversal mobility and density, and capture as well how the "reindeer crisis" brings into intersection a range of political rationalities, technologies for control and surveillance, modalities of accumulation, normative models of growth and modernity, incentive systems and their ramifications, discourses of morality, productivity, citizenship and responsibility and 
so on-an account, in short, of the crisis as a particular kind of "problematisation," an object and instrument of governance (cf. Foucault 2003; 2007; 2008; Li 2007).

The account I offer here is narrower than that, but it does form part of such an inquiry and goes some way towards it. Its principal aim is to develop a critical account of weight-based indicators in the management of Norwegian reindeer pastoralism: as instruments of assessment, control and regulation, but also of blame, manipulation and marginalization. Concretely, I am interested in deconstructing the normative microphysics of the weight concept, as applied to the bodies of slaughtered reindeer: both as a biopolitical metric, and as a kind of ontological determinant. Discussions of reindeer weight serve to structure debates, inform policy, reorganise practice and force into place certain kinds of herder-reindeer relations. Beyond that, however, I am also after the manner in which assessment practices in generaland here, perhaps quantitative metrics in particular-bring into existence certain kinds of world, and certain kinds of being, with certain kinds of attributes and qualities-and how, in the process, they may also occlude, preempt, erase and destroy others, rendering alternatives moot or counterfactual. I develop this point here by linking distinct modalities of reindeer assessment to the spatial logics they simultaneously entail and depend upon.

The main points of the argument are fairly easily summarised. In the dominant narrative of the Norwegian agricultural science-policy nexus, weight is pivotally implicated with a model of space as homogeneous, divisible, self-similar, persistent over time and predictable. This model of space profoundly contradicts another, pastoral logic of space, which for centuries has aligned reindeer and humans for survival across complex, heterogeneous, interdependent and continuously shifting terrains (see e.g. Mathiesen et al. 2013; Benjaminsen, Reinert, et al., forthcoming). Drawing out tensions between these two spatial logics, the argument explores how metrics, criteria and assessment practices simultaneously enmesh in and produce distinct kinds of space, with specific material properties and affordances. Condensed further, the gist here is familiar: indicators do not simply describe or evaluate-they can also erase, negate and render unviable, even unthinkable. Through valuation, certain things come into being; others may be preempted, foreclosed or destroyed. In the present case, this observation plays out in two ways: firstly, by bringing distinct forms of valuation into focus as differential ontological enactments, not just of the reindeer themselves but also of other entities entailed in the moment of assessment; and secondly, by drawing attention to the manner in which certain valuation practices may invalidate or preclude, not just alternative enactments of their object, but also other forms of valuation-effectively operating a kind of meta-valuation (and rejection) of valuation. This is one point of 


\section{Valuation Studies}

contact between my argument and long-standing debates over the relationship between "traditional knowledge" and scientific and statist knowledge forms (see e.g. Hobart 1993). It is worth pointing out, however, that my argument here does not rest on assigning inherent value to "traditional" knowledge as a reified marker of authenticity, or of romantic alterity. The tensions I outline are eminently pragmatic, circling around issues of power, survival and adaptation to complex, unpredictable and frequently inhospitable environments.

The stance I adopt does raise some pertinent questions for the social study of valuation and valuation practices: what is the place of critique, given the commitments of valuation studies as an emerging field of inquiry (see e.g. Haywood et al. 2014)? My own position here aligns broadly with Stengers', when she defines pragmatics as a "care of the possible" (Stengers and Bordeleau 2011). I am interested in how analysis can lend substance, and support, to modes of practice and existence that may-in some way or other-hover on the edge of the possible. In this context, the analytical deconstruction of valuation as a complex composite practice involving multiple rationalities is not incompatible with a pre-analytical commitment to-for example-the survival of marginal worlds, or of "subaltern" values and modes of valuation in general. If anything, such deconstruction forms a vital element of critical practice thusly imagined: capable of rendering the given as relative and the dominant as contingent, substantiating the otherwise-possible, disaggregating and multiplying practices in the same gesture. This is particularly pertinent to the case of reindeer pastoralism in Norway, which finds itself in a highly asymmetrical situation-where the largely uncontested truth-claims of a relatively small cadre of government-funded scientists completely dominate media and policy narratives, while indigenous counter-representations and critiques remain mostly absent or disregarded (Benjaminsen, Reinert, et al., forthcoming; Benjaminsen, Eira, et al., forthcoming).

Given the functional invisibility (and invalidation) of herder claims, set against evaluative practices that systematically present themselves as unmarked, transparent and objective-as belonging, that is, to a higher order of facticity than the "subjective" evaluations of herders themselves-the present text is a first attempt to invert the situation and subject the terms of the dominant narrative to critical deconstruction. Throughout, I adopt the stylistic convention of capitalising the term "state" as State-both as an ongoing reminder of its complex and problematic ontology, a nod to relevant debates (see e.g. Taussig 1992; Hansen and Stepputat 2001; Hobart and Kapferer 2012), and as an analytical shorthand that helps define the coordinates (and limits) of my argument. The Norwegian State does involve itself to an extraordinary degree in the management of reindeer pastoralism within its borders, relative to other states in the circumpolar region (cf. Reinert 2006; Reinert 2008). Alert, however, to "the danger of always 
being thought by a state that we believe we are thinking" (Bourdieu 1994, 1), my interest here is primarily with those forms and practices that inscribe State "action"-and that bring this involved, "active" State into being as pervasive, necessary, already-existent. The gist of my argument is to show how the evaluation of reindeer is implicated, ultimately, with conceptualisations not just of space, time and environments, but also of "proper" relations, governance, action and purpose. From this vantage point the State-and the world(s) it requires to exist-can appear as effects, as much as causes; their properties can be derived from the practices (including valuation) that compose them. Conversely, unpacking the hidden transcript of "other" valuations may well open up to us-as otherwise-possible, as possiblyreal-the world(s) these practices belong to, and that they might yet bring into being.

The argument is based on ongoing ethnographic research with reindeer pastoralists in northern Norway (see e.g. Reinert 2008; $2012 \mathrm{a}$; 2012b; 2014), and draws on interviews, participant observation and analysis of primary texts (speeches, government reports, grey literature and scientific publications) conducted over a number of years. Nearly all textual sources are in Norwegian; translations are my own. The argument is organised in sections. The next section briefly summarises the current role of weight in reindeer governance discourse, and in the ongoing reproduction of the crisis, based on a speech presented by the then-Minister of Agriculture to an audience in Karasjok, in the core inland herding areas of Finnmark in March 2012. The following two sections examine in more detail how weight functions in the context of density discourse and herd structure optimisation, both of which are key areas in the ongoing State effort to rationalise Norwegian reindeer pastoralism and bring it into the "present moment" of the State (Reinert 2012a). As a counterpoint to this material, drawing on a written account by a Sámi pastoralist, section five then sketches out an alternative modality of assessment, based on multidimensional criteria and complex, contingent interdependences. The penultimate section examines some issues that concern the relationship between spatial logics, "sustainability" and State power, while the final section draws together the argument and examines three questions that it opens up.

\section{Weight and Failure}

Weight matters. Particularly in recent years, the weight of reindeer has acquired almost totemic significance in Norwegian pastoral governance and administration. Along every axis-whether with regard to health, profit, productivity, welfare, survival rates or ethicsthe official discourse treats high weights as an unconditional good, low weights as a purely negative deficit. This predominance has substantive 


\section{Valuation Studies}

and far-reaching implications for herders and their practice, in large part because of the direct manner in which the State has since the late 1970 s become enmeshed in nearly all aspects of indigenous pastoralism in Norway: from regulating the size and structure of herds, to controlling prices, to limiting recruitment, to restructuring work units and determining the internal organisation of the industry (Paine 1994; Bjørklund 1999b; 2004; Reinert 2006). Within this regime of saturating presence, weight data-gathered from slaughterhouses and published annually by the Reindeer Herding Administration (see e.g. Statens Reindriftsforvaltning 2014)-has consolidated itself as perhaps the principal metric by which pastoralists, and pastoralism itself, are assessed and regulated. The current forced "reindeer number reduction" [reintallsreduksjonen] in Finnmark, for example, is being carried out based on estimates concerning the "sustainability" of districts and individual herding units - estimates which are based primarily on the weight of individual reindeer, averaged by age and gender. Herding districts (or units) with weight averages above a certain weight threshold are considered "sustainable": those below this threshold are being forced to reduce their herds, often dramatically, or face sanctions in the form of fines, subsidy cuts or-as the ultimate but still hypothetical threat-culling and mass forced slaughter. Through their reindeer, the predominance (and universal aspirations) of weight as a quantitative metric thus touches herders at the heart of their livelihood. Part of my aim over the next few sections is to deconstruct this predominance, examining how it comes about and the work it performs.

In early 2012, laying out the new agricultural strategy of the current Norwegian government at a public meeting in Karasjok, thenminister for agriculture and food Lars Peder Brekk stated that an "adjusted reindeer population, good animal welfare and good productivity" were the key for herders to achieve "legitimacy" and a "better reputation" - "both in Parliament and in general society" (LMD 2012). All three factors, in his account, were directly linked to the problem of weight: population, through an ecological discourse of density that defined individual weight primarily as a result of competition over resources, and thus as a direct function of the ratio between a population and the space (and resources) available to it; welfare, because-in the absence of more complex understandings of reindeer well-being (see e.g. N. Oskal et al. 2003; Reinert 2014)weight is operationalised as the principal indicator of reindeer condition, and therefore also their well-being (or suffering); and productivity, finally, because the weight of individual carcasses is also the primary measure of an efficient, optimally calibrated "herding system." The heavier the reindeer, the more optimally the available resources are being utilised and the more efficient production can be taken to be. The speech largely reproduced the familiar terms of 
government discourse on the subject, without major surprises. Departing from the prepared script, however, Brekk also went on to berate the assembled herders, accusing them of "whining" and herding reindeer "the size of kittens" — sparking a minor Sámi media storm, and drawing some rather pointed political commentary. The rhetorical exaggerations stood out sharply against the sober, prepared facticities of his speech-an apparent rupture of affect that personalised the stakes, while remaining consistent with the position of previous administrations. Leaving aside the performative politics of this dramatisation, it is the facticities that interest me here.

Drawing on a series of well-rehearsed tropes and arguments, Brekk's speech rendered the "thin" reindeer of Finnmark as highly visible bodies, marked by the loss of control, physical suffering and economic inefficiency: exemplifying the complex indexicality of weight, as a supposedly objective indicator but also as an instrument for localising, and concentrating, blame. The chain of operations he drew on-and reproduced-can be described fairly simply. I discuss its elements in more detail over the next two sections. First, physical weight is emphasised to the exclusion of all other indicators. Then, this figure is linked to competition over pasture resources, while a complex array of other factors that may also influence weight are minimised or excluded. Through a direct causal link between weight and survival, the loss of reindeer-not an infrequent or entirely avoidable occurrence, in the context of Arctic pastoralism-is then reformulated, progressively, as a purely human failure and the fault of "irresponsible" or "inefficient" herders, who fail to ensure optimal nutrition for their herds and, through this, expose them to all the threats and risks that a high weight would supposedly shield them from: predation, environmental factors, disease and so on. Weight thus becomes a discourse of failure, not only social and economic, or financial, but also moral: first and foremost the failure of herders, derelict in their duties to society and to their reindeer, but also a failure of the State itself, as the body that supposedly regulates them. Understanding this inferential chain more clearly-how it functions, how it plays into the current climate of crisis, and (crucially) how one might begin to understand the situation otherwise-requires a certain amount of exposition.

\section{Density}

In some form or other, reindeer numbers in northern Norway have been a managerial concern of the Norwegian State for as long as its knowledge systems have engaged with the pastoralism inside national borders (Bjørklund 1999a; Strøm-Bull et al. 2001). The concern with weight has emerged more recently, as an aspect of populational management parsed through improving technologies, novel and 


\section{Valuation Studies}

intensified modalities of surveillance, comparative productivity assessments and modernist discourses of rationalisation. Proximally at least, its current predominance derives in part from an influential report published in 2008 (LMD 2008a) by the Department of Agriculture and Food [Landbruks- og Matdepartementet, from now LMD]. This report was elicited by the most recent Reindeer Herding Act of 2007, which replaced the Herding Act of 1978 and outlined a new process for establishing appropriate resource management regimes, and maximal reindeer numbers, in the herding areas of Norway. As part of this process, the Act stipulated that individual reindeer herding districts were to develop their own "usage rules" [bruksregler] that ensured "ecological sustainability" (2008a, 3). To clarify what this requirement for "sustainability" entailed, in January 2008 LMD set up a working group-including representatives from herding districts, natural scientists, the herding administration and the government- to develop "objective" and "scientific" criteria for comparably and reliably assessing the sustainability of reindeer populations, ensuring a cohesive basis for governance of the total national reindeer population. The group delivered its report in June the same year, entitled "Criteria/Indicators for Ecologically Sustainable Reindeer Numbers" (LMD 2008a). This was then sent out for a threemonth formal consultation from June to September. Based on the consultation responses, the final output of the process was a set of "Guidelines for Establishing Ecologically Sustainable Reindeer Numbers," published in December 2008 (LMD 2008b).

The report itself is brief, only fifteen pages-without pagination, and including also both a questionnaire and a dissenting minority opinion from one of the committee members (2008a, 15)-but it makes for interesting reading. The authors outline four basic criteria for "ecologically sustainable" herding: it should not degrade pastures; it should maintain the "diversity of plants and animals" on the various seasonal pastures; it should ensure good animal welfare; and it should deliver reindeer of "high quality" for slaughter (2008a, 4). The report describes itself as a milestone: the first time reindeer herders, scientists and authorities have been brought together collaboratively to produce "holistic" targets and norms for sustainability by negotiating between the "scientific" knowledge of researchers and administrators and the "experiential" knowledge of herders (2008a, 4). Emerging from this encounter, the authors describe a "shared understanding" concerning the overarching interconnection between pasture quality, reindeer density on these pastures, the physical condition of individuals and the overall productivity of herding. Based on this "consensus"-despite reservations articulated in the minority report by the dissenting committee member, himself a herder, and endorsed by many of the consultation stakeholders-the report concludes that assessment of the ecological sustainability of herding should be based primarily on 
individual physical weight: specifically, the carcass mass of different age groups at the point of slaughter $(2008 \mathrm{a}, 9)$. Where necessary, this primary indicator is to be supplemented by other numerical indicators, such as live weight, meat production per reindeer and stability over time of the calf percentage (the overall proportion of the herd made up of calfs) in spring herds (2008a, 9-10).

The principal line of reasoning behind the focus on carcass weight is that individual weight reflects whether a reindeer is able to secure sufficient resources for optimal growth, in competition with other reindeer that also occupy the same space. Weight, in this framing, is a density dependent effect-or rather, perhaps, an inverse of density: a figure that captures a particular relationship between bodies and the pastures that support them. The higher the populational density in a particular area, at least beyond a certain point, the lower the weight of individual animals. Insofar as it reflects resource competition, and consequently also grazing pressure on the pastures, this version of weight can implicitly also index the condition of the pasture grounds, and thus displace the need to assess the latter directly. If the reindeer are "too thin," the implication is that excessive pressure is being applied to the pastures, and that this will degrade them-but this inference is valid only insofar as the condition of pastures can, in fact, be inferred more or less directly from the weight and condition of the slaughtered reindeer. To render the coupling between weight, density and pasture conditions robust, other factors that might affect the weight of individual reindeer-factors such as illness, timing of migration and slaughter, snow cover on the winter pastures, variable climatic conditions, long-term breeding strategies-must be eliminated from the equation.

Along these lines, the authors of the report do acknowledge that inferring pasture quality from weight is an "indirect" method, that weight is susceptible also to factors other than available pastures, and that reindeer numbers are not in themselves sufficient to fully measure "resource adaptation" in the "pasture system of herding." "Despite this," as the authors put it, the report still recommends that "average weight" at the point of slaughter for different categories of animal be used as the principal indicator of "sustainability" (LMD 2008a, 9). Alternative indicators and criteria, rooted in the "professional knowledge" of herders, are considered briefly but ultimately dismissed -as subjective and "difficult to measure"-and consigned to a subsidiary, functionally invisible role in assessment. The weight indicator, on the other hand, is "simple, objective and controllable"and therefore suitable for the purposes of the report. As the authors note:

the problem with both the more scientific and the more pastoral professional knowledge criteria is ... that they are affected also by oscillations in access to 


\section{Valuation Studies}

resources that are not caused by reindeer [population] density. This might be poor access to pastures because of weather conditions, ice on the autumn or winter pastures, significant rain and ice on the winter pastures, heat and insects in the summer and other disturbances caused by predators or human activity. As of today there are no fully adequate methods for measuring the effects of this on weight and on various production indicators. (LMD 2008a, 10)

This is problematic. Effectively, the authors are justifying the choice of carcass weight as the primary indicator of sustainability because it is measurable. Furthermore, because there are no "fully adequate" methods available to measure the complex interplay of factors that also influence weight-beyond density-weight is operationalised as a function of density. Criteria beyond weight-including assessment factors used by herders themselves, such as antler shape and thickness, pelt quality or overall body shape $(2008 \mathrm{a}, 9)$ - are considered briefly, but almost immediately sidelined as "subjective," i.e. not sufficiently "objective" or generalisable to develop as standardised indicators for assessment or control. Complexities of assessment that resist transformation into numerical indicators, and which are therefore difficult to incorporate within a standardised framework, are simply defined away.

The report goes on to specify the norms associated with the weight indicator. For calves, for example, the prescribed minimum weightrange at the point of slaughter-the weight that defines the lower threshold of "sustainable herding"-is set at between 17 and $19 \mathrm{~kg}$ (2008a, 11). Crucially, however, these norms are specified at the national level. To qualify as "sustainably" herded, the body of a slaughtered calf must now weigh the same across the length of Norway: from the relatively rich forested areas a few hours north of Oslo, where the southernmost herding districts are located near Røros, to the tundra on the edge of the Barents Sea, $2000 \mathrm{~km}$ further north and on the other side of the Arctic Circle. During the public hearing, a number of respondents drew out problems with the approach and recommendations of the report. In the consultation response from District 16, for example (LMD 2008c), herders in western Karasjoklocated in the inlands of Finnmark, some $300 \mathrm{~km}$ from Murmanskargued that the optimal minimum calf weight in their district was between 15 and $18 \mathrm{~kg}$, and went on to list a number of relevant factors. For one, their herds had a long migration route from the summer pastures to the autumn slaughtering sites, where the calfs would be slaughtered and weighed-much longer than the distances covered by reindeer in the south of the country, and entailing more significant weight losses for the young calves, who expended energy getting to the slaughtering site. They also pointed out that the climate in their area varied significantly from year to year, creating unpredictable oscillations in available pasture and therefore also in the weight of their reindeer. Transport bottlenecks, logistical problems and 
limited slaughtering facilities in the north affected the timing of slaughter, influencing the weight of animals at the point of slaughter: the reindeer might have to go in the corral for extended periods of time, losing weight, or the slaughter might be postponed until later in winter, by which point the reindeer would have consumed more of the body mass they had built up on the summer pastures. Finally, they argued, herders in their district had also bred their own local lineages of reindeer that were smaller in size than the national average, but of "good quality" and well adapted to local conditions.

Such objections-and others, from reindeer herding districts as well as other bodies and authorities involved in the consultation-were simply disregarded in the final guidelines, which reiterated that a carcass weight for calves of 17 to $19 \mathrm{~kg}$ was the threshold for "sustainability" (2008b, 3). Over the course of the subsequent "adjustment process," this figure was then progressively modified by actors within the LMD-in a series of internal seminars, workshops and memorandums, without herder consultation-until it reached 20 $\mathrm{kg}$ by 2013. This modified figure became the basis for deciding which districts, siidas and individuals were to reduce their herds or face punitive measures-although forced reductions were also ordered in districts with average weights above that minimum. Despite a dominant policy narrative which asserts pastoralists possess a high degree of "self-determination" (Johnsen et al., forthcoming), the opaque and top-down process for establishing threshold numbers in the "adjustment process" raises serious questions about government claims concerning the ability of herding districts to establish their own "usage rules" (Johnsen, forthcoming). Here, however, I want to focus on another issue-namely how, in discounting locally significant conditions, these new norms established a standard of "optimal weight" at the national level, within a national space imagined as (functionally) homogeneous: erasing geographical, environmental and social differences across the highly heterogeneous terrains of herding.

As the objections from District 16 indicated, the idea of a normative standard weight at the national level eliminated pertinent differences in climate, topography, weather conditions, infrastructure, breeding strategies and social organisation-factors which might affect not only the weight of reindeer, but also their "optimal" weight as an adaptation to local conditions. Consider, for example, a northern district with summer pastures on islands along the Finnmark coast. Conditions during the summer for newborns may be peaceful and abundant, with little or no disturbance, producing relatively fat, heavy calves-possessed of an "optimal" physiognomy, at least as encoded in State directives. Once these calves migrate to the mainland, however, and encounter the harsher conditions on the winter pastures, they may fare worse, with lower survival rates, than calves who have spent their entire lives on the mainland. The latter may have lower weights, but 


\section{Valuation Studies}

they may also be in better condition, resilient and accustomed to harsher conditions. Herder accounts suggest that despite being heavier, island-born calves often may succumb more easily to environmental conditions encountered on the mainland: low temperatures, exposure, predation, limited feed.

With predation, similarly, the official discourse of the Norwegian science-policy nexus presents high weight as a near-universal counter to losses, while herders themselves describe weight as playing out in a more complex, differentiated manner-depending on a host of other factors, including the type of predator involved, their hunting strategies, their favoured mode of attack, their preferences with regard to prey, environmental and seasonal conditions, terrain type, the structure of the herd, the experience of other nearby reindeer with fighting off that particular kind of predator, and so on. Across certain types of snow terrain, for example, a light calf might have the advantage over a heavier one-as the heavier calf may punch through layers of ice in the snow cover, sinking deeper into the snow and losing speed, while the lighter calf gets away. A large range of other examples could be adduced here: the short of it is that in herding practice, weight generally functions neither as a context-independent index for condition, nor as a universal predictor of survival. The link between weight and survival appears nowhere near as transparent, obvious or self-evident as the dominant discourses of the science-policy nexus indicate.

\section{Structure}

I will return to these issues shortly. For the moment, let me summon up another set of concerns that converge in the idea of weight. Consider this: the Norwegian reindeer (rangifer tarandus) gestates for an average of approximately 288 days, between the autumn breeding season and late spring of the following year. Dams usually birth only one calf a year, between April and early June-the seasons referred to as Giđđa (spring) and Giđđageassi (spring-summer) in northern Sámi. The life of a semi-domesticated reindeer makes the young calves highly vulnerable, certainly by the standards of more "conventional" livestock industries. In their first year they may succumb to accidents, environmental exposure, malnutrition, disease or predators such as lynx, wolves, wolverine and eagles. Of the majority that survives through the summer, most are taken out and slaughtered at their first or second seasonal round-up, when the herds are gathered up in corrals for husbandry operations (Paine 1994; Reinert 2014). This is also the point where most of the calves are marked as belonging to their human owners. Watching the animals closely, often from a distance, herders can identify which cow each calf follows, and assign (human) ownership according to (reindeer) descent. Each calf is 
assigned the earmark of its human owner, as a pattern of cuts in its ears (Bjørklund and Eidheim 1999).

From birth to the start of the autumn slaughtering season, the reindeer calves grow very fast. As they age, the weight-gain slopes off, but it remains high through their second and third year, particularly for the males. The shape of this weight-gain curve has economic implications. The older a reindeer gets, the more pasture resources it consumes simply to maintain its body mass, rather than add to it. Rapid early growth thus makes calves a more efficient channel for converting available pasture resources into meat, and from there into economic value and profits. As a result of this, slaughtering the young has for some time been the primary focus of government strategies to maximise the meat output and "efficiency" of pastoral practice. Such slaughter strategies are well known from other agricultural sectors; in the Soviet Union, experiments with using them to rationalise reindeer herding date back as far as the 1930s (Holand 2007). In Scandinavia, models and principles for calf-based production strategies were methodically tested out and developed in the Røros area from the 1970s, as part of a modernisation strategy to "improve" herding practice, rendering it more profitable and efficient (Reinert 2006; Borgenvik 2014; Benjaminsen, Eira, et al., forthcoming).

This "rationalisation" played out mostly along lines made familiar by other "development" interventions of that period, elsewhere in the world (Hobart 1993). Norwegian rationalisers interpreted the diversity of indigenous herd structures - in terms of age categories, animal types and sexes-as "irrational" and disorderly, and proceeded to design and implement "optimal" herd structures that would fulfil the objective of maximising meat production. Little or no attention was paid to existing principles of herd composition, or to the various objectives that diversified herd structures fulfilled-from defending against predators, to ensuring a diversity of inherited traits and resistances (e.g. to temperature, insects or disease), to the cultivation of aesthetic and moral values involved in maintaining a "beautiful" herd (N. Oskal 2000). Assumptions about herding as an indigenous practice-rooted, in no small part, in colonial discourses of race and ethnicity (Reinert 2012a)—enabled these existing adaptations to be dismissed out of hand: as inefficient at best, at worst as ignorant, primitive or irrational (Bjørklund 1991). According to a 1982 article by Dag Lenvik, a leading architect of the so-called "structural rationalisation" [strukturrasjonalisering], the objective of the new "rational" herd was to:

improve gender structure, age structure and growth structure in the reindeer herd. All these structures must be ordered and optimised if one is to take out maximal meat production per spatial unit of grazing land through reindeer herding (Lenvik et al. 1982, 62). 


\section{Valuation Studies}

The overall mandate here-to "take out" the maximal amount of meat per unit of grazed land-was beyond question. In line with this goal, the new principles of scientific rationalisation required significant changes in herd structure: the new, "scientific" herds were to be constructed according to "rational" principles, supported by empirical studies. Meat production was to be based on a continuous turnover of calves, "produced" and "harvested" each year in the highest possible numbers. To ensure maximum production of calfs, herds were now to be composed mostly of heavy and highly fertile females, selected for early and consistent breeding, with a minimal complement of males, as required to fertilise them. Young females should breed by their second year, ideally, and continue to "produce" annual calfs until their fertility dropped off and they could be slaughtered. Calves should be as heavy as possible, of course, to optimise the meat yield per living animal.

In pursuit of efficient structure and optimal resource utilisation, the so-called "Lenvik model"-also known as the "Røros model"castigated and tried to eliminate supposedly "irrational" elements of traditional herd structure (Borgenvik 2014). Lenvik himself, for example, judged sternly the traditional practice of maintaining herds with more reproductive males than necessary for reproduction:

Within normal sheep rearing, meat production based on old non-castrated rams is unthinkable. No sheep farmer would use the winter feed-the marginal factor -on a herd of rams that produce less meat than the ewes can produce through the yield of lambs. Today, the line of thinking should be the same in reindeer herding. Male animals that are superfluous from the point of view of procreation occupy grazing grounds that could be better utilised for cows (Lenvik 1990, 31$32)$.

Within the parameters of this model, male reindeer were reduced entirely to their reproductive function. Beyond the minimum complement required to fertilise the females of the herd next year, males were framed as an unproductive and irrational surplus: excess bodies that consumed vital resources on the scarce winter pastures, without generating returns in meat. In order for the males to be reconstructed this way, however, all possible variables and events that might have rendered them useful or valuable on the winter pastures first had to be bracketed off and eliminated: their greater ability to fight off predators, for example, or other skills and patterns of behaviour that might otherwise facilitate the survival of the herd. One might say this reduction of males to their reproductive value was tautological: valid in practice only if, or as long as, the herd was maintained in an environment where such pressures did not obtain. As soon as relevant environmental pressures are introduced and taken into account, the pragmatic value of males begins to exceed mere reproduction; and this is leaving aside the wide range of other factors - such as aesthetic preference, herding strategy, behavioural control 
over the herd, terrain types along the migration route, available manpower for herding - that might also influence their role in herd composition. I return to these in the next section.

Clearly, the Lenvik model forms parts of a wider movement in the twentieth century, towards the reorganisation of agriculture along the lines of industrial mass production. Nationally, its implementation also aligns with a very strong emphasis on centralisation and standardisation in Norwegian agricultural planning, throughout the second half of the century (Reinert 2006). As Lenvik's comparisons to sheep rearing indicate, its advocates and developers also relied to a significant degree on models (and concepts) imported from Norwegian agricultural and livestock management traditions. Importantly, the model was based on experiments and data from the southern herding areas, located in the temperate mid-country. In part, its local successes there can be ascribed precisely to local conditions: the climate there was far milder, the vegetation richer, surveillance easier, the density of herders lower than in the northern territories. The open-air "experimental" environment in which the model was developed supported its abstractions, offering limited resistance and tending to produce the desired results on a fairly consistent basis. The model fit its environment, and vice versa. Lifted to the national level however, and transformed into a kind of "immutable mobile" (Latour 1987), the Lenvik model encountered a range of novel conditionsparticularly as it moved north. Faced with these, the model continued to sustain the experimental invisibility of its original conditions. To this day, proponents of the model still generally disregard the specificities of climate, economic and social context, spatial logics, predator distributions, cultural forms, local stakeholder and interethnic relations and so on that enabled its assumptions to work (while also remaining unstated) in their original setting. Rather than adapting and taking into account local variables elsewhere, the model and its projections generate comparative assessments of pastoralism in these other environments as "inefficient," or "irrational." The question becomes not how the model could be adapted to different environments, generating alternative models of "optimal" herd structure, but rather why local practices elsewhere fall short of the model.

\section{Reframing Assessment}

In short, then, the Norwegian statist discourse on reindeer assessment tends-very strongly—towards highly simplified, single-indicator management, based on comparabilities established through numbers and quantification (Porter 1995; Scott 1998). This narrow focus affects pastoral practice directly, e.g. through the structuring effect of subsidy schemes, and indirectly, insofar as it reorganises the strategies and 


\section{Valuation Studies}

priorities of herders within a field that is in large part defined-and dominated-by the State. Effectively, it redefines the parameters of relevant knowledge. Attempts to render the messy complexities of pastoral practice in qualitative terms are generally disregarded, treated as inferior or anecdotal rather than valid representations of practice in challenging, complex and frequently inhospitable environments; the "rationalisation" of herding operates simultaneously across multiple domains, simplifying more than just herd structures and terminology. Of course, one basic problem of rationalisation discourse, as amply documented in critiques of development interventions elsewhere around the world, is that it redefines existing knowledge, traditions and institutions as "irrational," as forms of ignorance or underdevelopment (Hobart 1993). In rejecting indigenous criteria, the authors of the 2008 report (LMD 2008a) played into a complex and well-documented history of indigenous knowledge being displaced and erased in the administration of Norwegian herding (Bjørklund and Brantenberg 1981; Paine 1994; Bjørklund 1999b). Beyond this however, the mandate of the report also predetermined a particular sort of simplification: a sacrifice, or erasure, of certain kinds of empirical complexity, in the pursuit of governability, operationalisation and standardisation.

Part of the problem with the predominance of weight is thus that its quantitative "objectivity" enables the dismissal of alternative forms and principles of assessment-including what proponents call "indigenous" or "traditional" knowledge-as irrelevant: a dismissal which then tends to confirm itself, as herders pragmatically orient their own practice towards requirements encoded (for example) in the subsidy systems they depend on. But what are these "traditional" modalities of assessment? How do they function, and how do they contrast with numerical indicators such as weight?

Herders themselves assess (and value) their reindeer using a bewildering array of technical terms, for a wide range of purposes, in highly context-dependent ways. The complexities of traditional pastoral description and selection practices have been documented in some detail elsewhere (see e.g. Paine 1964; 1971; 1994; Sara 2001). Here, for clarity, I will limit myself to discussing a representative textual source. Speaking at a 1998 conference in Tromsø, in a lecture entitled "Traditional assessment of animals for slaughter," the reindeer herder Anders Isak Oskal outlined some of the criteria traditionally used by herders to select reindeer for slaughter (A. I. Oskal 1999). His lecture was informal in tone, based on his own experiences as a herder and chairman of the reindeer herder association in Kautokeino. Oskal began by outlining three principal modalities of pastoral assessment: based on genealogy or descent [avstamning]; on behaviour, or personality; and on appearance, i.e. morphology. "Appearance," as Oskal used it, might include such factors as the quality, pattern and 
colour of the pelt; the size and physical appearance of the reindeer (small, large, magnificent, thin); and the shape or quality of the antlers. Assessment based on "behaviour" might include determining whether the reindeer was tame or shy, flighty, passive, responsive, uncontrollable, dominant or easily led, gregarious, solitary, curious or docile or aggressive, as well as assessing the role and position that it usually adopted within the herd, at rest or in motion: did it keep to the front, to the back, to the middle, to the edges or flanks of the herd? How far did it range from the herd when at rest-or, conversely, when the herd was moving? How did it interact with other reindeer? Assessment by appearance and behaviour in turn overlapped with a third mode of assessment, "descent," which could be evidenced in either of the others: in traits of appearance or of personality that were passed on from generation to generation, enabling a knowledgeable herder to identify the genealogy of an individual reindeer through recognition, and to select reindeer for slaughter based on an intimate, familiar knowledge of lineages, as well as of the various traits represented in the herd, balancing their desirability against each other over time.

Such understanding of individual traits, and of the herd as a complex living aggregate, was required to manage the herd across the range of particular terrains it would encounter. Composition and herd structuring here figured as a complex, intuitive and context-dependent art: a matter of skill, insight, experience and aesthetic sensibility, put to work with specific reindeer in specific environments. Experienced herders might recognise the shifting quality of a whole herd at a glance, assessing its relationship to its surroundings and discerning the entirety of traits and relations that made it up, then using this knowledge to "shape the herd using every living animal in it" (A. I. Oskal 1999, 123). A range of technical expressions were available to describe the qualities of a reindeer herd as a whole: it might be "beautiful" (cappa; good reindeer and appropriate structure), or "thin" (skarba; few bulls, or none), or "tame" (lojes; needs little herding), or "shy" (skirce; skittish, easily scattered), or "willing to wander" (mannis; easily moved, e.g. during migrations). Individual traits impacted in complex ways on the behaviour of the herd as a whole-through their interaction, their balance and the proportion in which they were present within the herd. Skittish or shy reindeer might be difficult to handle, say, but as long as they were not predominantmaking the herd difficult to control-they could also be important for moving the herd, as they tended to lead the more sedate reindeer in the centre and make them move on.

While brief, the Oskal lecture draws out an overwhelming richness of terminology, a body of multi-dimensional assessment criteria that informed the composition of the herd as a complex and internally differentiated living entity, in constant interaction with a specific range 


\section{Valuation Studies}

of dynamic, continuously shifting environments. Of course, what Oskal describes here is not a comprehensive or reified "system of knowledge" shared by all herders: herding strategies and herd composition principles vary from district to district, family to family, individual to individual. What his account does make clear, however, is the manner in which the complexity of these assessment criteria mirrored-and was oriented towards-the spatial complexity and heterogeneity of specific material environments: an observation that strongly dovetails with accounts given by other herders, both published (see e.g. Sara 2001) and in conversation (Reinert 2008). As a key instrument for controlling the structure of the herd and guiding its growth, slaughter selection must take into account every aspect of the life of the herd, and those of the herders that depended on it. How far did the herd have to travel between the summer and grazing grounds? What sort of terrains did it have to cross on its migration routes, what were conditions like along these routes, what difficulties was the herd likely to encounter this year, next year, the year after? What qualities did the herd as a whole require to thrive, to survive what would happen-and not succumb to what might happen? Different types and age categories, present in different proportions, would alter its behaviour, supporting different strategies of control. The presence of visually distinctive reindeer for example, say with clear markings or unusual features, made the herd easier to recognise at a glance, facilitating the work of management-particularly on the summer grazing grounds, where herds were generally more dispersed. Slaughter selection served to eliminate undesirable individuals, to control the survival and transmission of traits, to regulate the ratios and proportions of different classes of reindeer within the herd and, ultimately, to manage, modify and control the herd itself: as a living aggregate, irreducible to the qualities of particular individuals. Selection for slaughter was thus a highly skilled, entrained aspect of herd composition, refined over centuries of practice, that took the structure of the herd into account as a weighed, negotiated compromise between a range of concerns, priorities and considerations. The complexity of assessment criteria, practices and terminology reflected this directly.

It is difficult today to estimate the overall distribution of assessment practices such as those Oskal describes: in part, because strategies and traditions have always varied from district to district, within families, between individuals. As a whole, there is little doubt that herders have adapted in a pragmatic manner to the parameters set (and reset) by government policy - to various degrees, and with mixed results. Some districts report successfully improving their economic situation by adopting government recommendations concerning herd size and structure. Many others, particularly in the northern core herding areas, describe unrealistic government mandates and interventions disrupting 
the material, social and economic basis for their herding practice, making life impossible. Concern for the future of the industry is marked, and growing. An underlying question here-there are many others-is whether adaptation to government parameters may be jeopardising the much longer-standing adaptation of pastoralism to its own material environments: environments which are complex, heterogeneous, unstable and poorly accounted for within the spatial paradigm that underpins most administrative interventions (Scott 1998; Benjaminsen, Reinert, et al., forthcoming).

\section{Space}

As I discussed above, standardised national norms render weight as a quality that can be optimised, to the same specifications, independently of local conditions. Through this, it seems fair to say that the notion of weight also participates in a reproduction of space as homogeneous, within the familiar spatial imaginaries of nation and State (see e.g. Anderson 2006 [1983]). Let me develop this point a bit further, and connect it to some of the other issues raised in the previous three sections.

Through a series of visual and mathematical operations, density discourse transforms the complex terrains of herding into a featureless, internally undifferentiated expanse-divisible to infinity, into fungible and undifferentiated fractions. Within this model of space, lost pasture-grounds figure simply as deductions from a more or less undifferentiated total quantity: in other words, pastoral space is rendered as inherently subject to arithmetical subtraction. At the same time, and analogously, programmatic efforts to "rationalise" herd structure operate with an equally abstracted environment. "Environment" disappears in the Lenvik model, becoming invisible to the exact degree that it fails to make meaningful difference to issues such as herd structure. Decoupling herd structure from the local specificities of space, terrain and environments, State pastoral governance reflects an apex of de-specification: a multiple dematerialisation that gives us the imaginary "ideal" herd, moving through imaginary "ideal" environments located in an imaginary, featureless space; abstractions, mirroring each other to infinity. Inactive environments and undifferentiated terrain express, I suggest, the same underlying logic: a Cartesian model of space as an abstract, "empty" and domesticated medium-a "barnyard space" aligned, more or less impeccably, with the cadastral metageography of the State (Scott 1998; Reinert 2008; Benjaminsen, Reinert, et al., forthcoming).

This version of space-and implicitly, the versions of reindeer, herd and pastoralist that it entails-are at odds with the spatiality of herding and herding practice as described not just by Oskal, previously, but also by most herders. Reindeer rarely stay in one place 


\section{Valuation Studies}

very long: with their herders, they make sequential use of highly differentiated seasonal pasture grounds, continuously shifting between pastures, and between microclimatic niches within each pasture area (Reinert et al. 2009; Reinert et al. 2010). The space that they constitute, through grazing and migration, is discontinuous, highly differentiated and unpredictable, potentially unstable: a patchwork of complex interrelated terrains with multiple shifting uses, depending on climate, environment, pasture conditions, the timing of seasons, predator pressure, insect presence, human disturbances, other factors expected and otherwise. Herders describe this space using terms like jabkodat-a term that captures the distinctive seasonal structure of any given year, as a composite of variable and interdependent factors with cumulative effects (Sara 2001; Benjaminsen, Reinert, et al., forthcoming) - and in proverbs or maxims such as "one year is not the brother of the next" ("jahki ii leat jagi viellja") (Tyler et al. 2007).

"Space" emerges here through the situated practice of humans and reindeer moving through territories that are complex, singular and highly differentiated-in which no simple identity or equivalence obtains between one terrain and another, and where the substitution of one specific territory for another is at best contingent, a compromise that becomes more difficult with each forced substitution, and at worst impossible (Bjørklund and Brantenberg 1981). Within spaces of this kind-variable, discontinuous and unpredictable-the loss of particular areas to developers, to roads or infrastructure, to windmill parks or mines or noise pollution can not be understood merely as subtractive. Rather, the impact of progressive encroachments is disruptive, wide-ranging, with knock-on effects that ramify through the entire "herding system" in ways that are hard, sometimes impossible to predict. This problematic disappears almost entirely in weight-centred crisis discourse-in no small part, because of the manner in which weight renders a particular understanding of space simultaneously axiomatic and invisible.

Countering the effects of such spatial assumptions-as manifest, for example, in the censures, restrictions and punitive measures of the ongoing "reindeer crisis"-places a continuous drain on the resources of herders, who are forced to commit substantive time, energy and critical efforts to the multiplying task of representing (and defending) the spatial logic of their practice. The putative reindeer excess exists as a surplus of bodies relative to the total grazing capacity of a given territory-a spatial totality which, from a pastoral perspective, appears "thin": homogeneous, abstract, disarticulated from its concrete specificity and use value as this varies over time, between seasons and according to unpredictable variables. Effectively, two quite distinct logics of space confront each other here: on the one hand, space as an abstract, stable Cartesian medium, indefinitely divisible into units of internally undifferentiated, fungible space-each possessed recursively 
of the same basic (lack of) architecture; on the other, space as a fluid, extemporaneous practice; singular, specific and multiply differentiated, emergent in an ongoing, more-than-human interaction between heterogeneous agencies.

It is worth noting, at this point, that by articulating weight as a territorial problem-i.e. as a distribution of bodies in space-density discourse activates the State in a biopolitical modality, as a power that concerns itself, precisely, with issues such as the distribution of living bodies in space. The operation of the State in this modality, with an enforceable mandate to ensure "optimal" distributions of living bodies, is not itself in any way a neutral or value-free undertaking-however successfully it may present itself simply as a technical approach to a technical problem ( $\mathrm{Li}$ 2007). "Sustainability" is a key term in the discursive universe of the reindeer crisis-but in the argot of current government missives, reports, conference presentations and speeches, the concept is subsumed, more or less entirely, within the long-standing government project to " $\mathrm{fix}$ " the reindeer population, by calibrating it to available pastures: specifically, for the purpose of generating the maximum amount of meat, and thus maximal revenue, while still also ensuring the maximal regenerative productivity of available pastures. In other words, the notion of "sustainable" is coupled to an imagined point of maximal productivity, conceived as an ideal, perfectly calibrated juncture between weight gain, birth rates and the regeneration potential of pasture resources. High profits become, effectively, an expression of sustainable herding; sustainable means not just profitable, but maximally profitable.

At first glance at least, this seems to disarticulate "sustainability" from concerns such as preserving the livelihood of future generations (WCED 1987)—or rather, one might say, it articulates the future survival of pastoralism in very narrow terms, as contingent (often in unclear ways) on maintaining its maximised economic profitability in the present. With this, "sustainability" is emptied of critical valence, reduced to a formalisation of productivist logic that encodes the drive to maximise resource exploitation. The complex realities of pastoralism as a traditional indigenous livelihood, with its own language, customs, traditions, ethics and pedagogy, fall outside the scope of intentional sustainment: at best, their survival is treated as an automatic byproduct of economic optimisation. Mirroring the transformation of the herd operated by the Lenvik model, pastoral practice itself is re-imagined as a kind of machine-more or less efficient, more or less optimised-whose purpose and objective is to transform pastures into meat. The legitimacy of this "machine" stands or falls on its ability to generate optimal economic value from available territories. Production levels that fall short of the theoretically "ideal" level are penalised as "unsustainable" and serve as the basis for public chiding and denunciations, as well as threats of 


\section{Valuation Studies}

violent intervention-such as mass culls and forced slaughter-to "correct" productivity, supposedly for the sake of future generations. This coupling between sustainability, revenue maximisation and State power is troubling, complex and-at least in the context of Norwegian pastoralism-highly under-analysed.

Judging from the current tenor of conference presentations, strategy documents, speeches and media interventions by "official" actors, there seems to be a shift taking place in the public rationales for State intervention into pastoralism: from a long-standing rhetoric of ecological disaster, towards a range of economic arguments that focus on inefficiency and maximising revenue. Through these, the State appears to be investing itself progressively with the justified power to intervene when, for whatever reason, the productivity of pastoralism is not "optimal." In this light, the issue of reindeer weight presents a crisis for the State in a very particular capacity-that is, as an agent responsible for ensuring the maximal generation of wealth, from available resources within its territory. This version of the State, and the mandate that flows from it, forms a vital but still poorly described dimension of pastoral governance in Norway-one with complex historical roots, linked in part to the ideals of the post-WWII reconstruction, the rise of the Norwegian welfare state in the $1950 \mathrm{~s}$ and the links that were forged at the time between notions of material wealth, living standards and welfare (see e.g. LMD 2002, 36). In a broader historical sense, of course, the imperative to maximise yields from a given territory forms part of a logic of governance that is traceable back to John Locke, to the earliest colonial ventures of European states and to the moral theories that justified the expropriation of native land (Kolers 2000). Across the world, this logic of territorial optimisation has functioned to displace indigenous livelihoods, justifying their elimination in favour of activities that generate higher yields-and which therefore appear more profitable, more efficient and also more valid (N. Oskal 2001). This problematic extends beyond my present remit, but it is nonetheless worth asking how practices of assessment, quantification and spatialisation may articulate with and extend historical patterns of State power and colonial violence-and whether the profitability of space should really serve, today, as the prime metric for indigenous policy in a State that positions itself as a signatory to international treaties such as ILO Convention 169.

\section{Conclusion}

As others have observed for decades (see e.g. Bjørklund and Brantenberg 1981; Paine 1994; Bjørklund 2004), the field of reindeer management in Norway remains defined, in large part, by an enduring disjunction between administrative theory and pastoral practice-a disjunction that is represented, frequently, as a simple deficit of 
information (or rationality) on the part of herders. Against the grain of this, my argument here re-inscribes the disjunction as a point of articulation between ontologically distinct spatial logics, and explores the role of assessment practices and criteria in reproducing it. Using material drawn from interviews, literature analysis and ongoing ethnographic fieldwork, I have tried to illuminate the present-day microphysics of this disjunction, as they play out against the backdrop of the ongoing "crisis," and sketch out some of the ways in which weight intersects-as a metric, indicator and attribute-with differential imaginaries of space, biopolitical rationalities, histories of systemic erasure and invisibility.

In the context of the reindeer crisis, "weight" is first and foremost the most recent iteration of a persistent pattern-a concept of excess that has structured Norwegian reindeer policy since the middle of the nineteenth century, enduring through successive governments and changing regimes, redrawn national borders, the advent of electricity and fossil fuels, motorisation, one World War and the next... Arguments and justifications have shifted over time, variously framing the "problem" of herding as a matter of geopolitical security, nationbuilding and national integration, economic development, welfare reform, ecological ruin and desertification (Bjørklund 2000). A key common thread, through these iterations, has been the notion of "too many reindeer" - a ghostly refrain, persisting in the amber of policy. The present essay has been an initial effort to describe some of the ways in which disjunction and excess alike are produced, and constituted, through indicators and structured practices of evaluation. Let me close with three questions.

Firstly: what is "weight," and what is the work that it does? Based on what I have outlined here, I suggest that the metric of weight operates in at least three distinct modalities. Disaggregating these may help clarify the question. One modality is spatial, treating weight as an inverse of density - as a relationship between bodies and space-and seeks to perfect it through an optimal distribution of bodies in space. A second modality is eugenic, insofar as it "optimises" weight as an effect of human genetic selection and control exercised over time, from generation to generation. In contrast with the first, this second modality perfects weight in time, through the iterative, genealogical manipulation of bodies with the aim of fostering "improved genotypes"- - understood as bodies that yield an ever higher output of meat. Of course, as Oskal indicated above, eugenic selection has also been a key instrument of pastoral control-but in the context of traditional pastoral selection, such control functioned with a much larger set of criteria (and objectives) than it does within the productivist parameters of the current governance paradigm. From a pastoral point of view, both modalities-density discourse and productivist eugenics-operate through dramatic simplifications: of 


\section{Valuation Studies}

space, environments, value and of the reindeer themselves, transformed from complex, adaptive, more or less autonomous beings-possessed not only of multiple possible values and uses, but also of a fairly complex ethical personhood (N. Oskal et al. 2003; Reinert 2014)—to ciphers in a mathematical calculus of maximised production. A third modality, supplementary to the other two, manipulates weight at the aggregate level: seeking to optimise the total, "harvestable" weight through structural recompositions of the herd as an aggregate body. Ensuring the maximal weight of individuals, in this framing, depends on ensuring a maximally efficient herd structure-that is to say, a herd without "surplus" individuals, such as non-reproductive males, who consume the scarce resources of the winter pastures without transforming them into meat output for the market. Weight is thus maximised through structure, set against the available resource basemediated by a spectral model of the "ideal herd," as an abstract machine that maximises its own total mass by transforming available pasture resources into meat as efficiently as possible. Taken together, these three overlapping logics mark out a set of biopolitical parameters, rooted in a particular model of human-animal productivity, of optimisation and (implicitly) of relation-a model that depends, among other things, on a certain understanding of space as "empty," homogeneous, fungible, indefinitely divisible and predictable: a totalising frame, within which alternative, less-quantifiable forms of life, relation and assessment can be erased-or, at the very least, rendered irrelevant. Needless to say, again from a pastoral perspective, these simplifications - of lived practice, environments and relationships -are dramatic, bordering on the brutal: the ghost of a herd, repetitively moving through a featureless and unchanging terrain, forever.

A second question, then: what is a reindeer, and to whom? ${ }^{1}$ What can it be? One of the key issues here-in the context of weight discourse but also more generally, in the rendering-legible of Norwegian reindeer husbandry as an object of governing knowledgeis simplification (Scott 1998; Li 2007). Attuned as they were to the situated contingencies of continuous interaction with complex, dynamic and heterogeneous environments, pastoral assessment practices traditionally accounted for reindeer with dozens of relevant traits: lineages and biography, dispositions, abilities, individual personalities. The new "optimal" reindeer, on the other hand, possesses only a handful of significant traits-age, gender, weight, fertility and (in aggregation) density - all of which are ultimately compressible to the issue of maximised meat production: weight, as the input and output of slaughter; fertility, as the ability to regularly and predictably

${ }^{1}$ I have been addressing this question in different ways for a while now (Reinert 2008; 2012b; 2014). For a comparative formulation, see Vitebsky and Alekseyev (2014). 
generate more bodies with high weights; and density, which derives weight as a function of the distribution of these bodies in space. Through the lens of the "new reindeer," as one element in a "production system" for meat, the herd and pastoral practice alike are re-conceptualised as a highly simplified aggregate, moving through highly simplified environments and defined via a small number of quantified variables-all balanced against each other, in a system of calculable tradeoffs and optimisation. This is pastoralism and the herd within a logic of the total system, of calculative State biopolitics and the synoptic god-trick view "from nowhere" (Haraway 1988)-as an economic abstraction, stripped of "cultural" specificity, worlds removed from the concrete complexities of day-to-day survival in the challenging, continuously shifting environments of the Arctic. ${ }^{2}$ At the same time, other forms of complexity-from mathematical projections of risk or growth, to the predictions of ecological population modelsinform, substantiate and support not only this "simplified" herd, but also the assessment and valuation practices that reproduce it. In one sense, moving beyond simplification, the weight issue opens onto what one might call the political economy of complexity-that is to say, the manner in which different forms of complexity are privileged (or dismissed) through their alignment with social, legal, political, economic and institutional factors.

A third and final question, then: what is at stake, in the question of assessment? I have sketched out some provisional answers to this already; allow me, in closing, to focus the issue more narrowly. Beyond numbers and rhetoric, the reindeer crisis in Norway is fundamentally a problem of space: the progressive, inexorable bleed of pasture areas lost piecemeal to competing spatial interests; the opening, and increased availability, of pasture grounds to a growing population of stakeholders, old and new, equipped with rapidly improving technologies that enable new forms of access, utilisation and value extraction; the long-standing disconnect between pastoral practice and administrative understandings of the pastoral space through which herders move, and that they occupy with their herds; shifting global patterns of resource use and availability, which are transforming and reorganising the spaces of herding as the focus of international attention (Johnsen 2014). These are all matters of increasing and cumulative urgency for herders, with tangible day-to-day effects. To put it in the simplest terms: a modality of assessment that dismisses or

2 Of course, over time, these simplified models have modified the practices they regulate. As Oskal argues, for example (A. I. Oskal 1999, 123), decades of government interventions and regulatory schemes have forced herders to modify their herds and practice, leading to "poor herds," with poor composition-designed only to meet official production requirements, without taking into account the behaviour of the herd, its relation to local environments or other qualities that might otherwise be important. 


\section{Valuation Studies}

disregards the spatial complexities of Arctic pastoralism, rendering invisible its specific affordances, is-necessarily-inimical to the survival of pastoralism, both as a practice and a mode of life. I have argued here that the assessment metrics of the Norwegian sciencepolicy nexus depend on (and reproduce) an understanding of space that is almost entirely foreign to the spatial logic of Arctic pastoralism, and which is in fact antagonistic to it. Over time, the effects of this disjunction are making themselves increasingly felt.

A more general point to be made here concerns the manner in which assessment practices simultaneously specify and make invisible their own context and conditions of possibility: erasing what falls outside and rendering as given the worlds they describe, worlds which also make them intelligible in turn. This double move can amount to a foreclosure, an invisible colonisation of the unseen, a short-circuit of the inexplicit, of the difficult and subjective-no less so, certainly, when put to work in the service of dominant interests. Framed in this way, assessment presents itself as a problem at the intersection between power and ontology, or ontologies in the plural (Holbraad and Pedersen 2014): not just a matter of measuring, of "better" or "worse," of more or less "accurate," but of what can exist, what should exist, of how and on what terms it should be allowed to do so. Thus understood, issues of assessment and valuation compel attention not only to power, but also to givenness and absence, facticity and retroaction: to "common sense," to unnoticed absences and unmourned eliminations - to the worlds being made, and unmade, in the moment of assessment.

Conjured in the rationalising calculus of productivist State discourse, the "ideal herd" occupies an abstract ideal space, largely free of predators, within which disturbances occur as occasional disruptions in an otherwise stable environment. Factors that vitally and unpredictably determine the lives of pastoralists and their herds are either assumed absent, or assumed subject to human agency and control-and when these factors do appear, manifesting their disruptive agency, human control is invariably assumed to have failed. This is the blank, homogeneous space of density discourse: a Cartesian space, given as fully known to its (supposed) human masters. At its most basic level, I think, this is also the space of the State's dream of itself, of its own sovereignty over space-seamless, unbroken, featureless and internally undifferentiated, coherent from border to border, all the way. Power dreams the spaces it creates as if untouched, as a pre-existing medium, uniform and empty: a homogeneity extending through space as it does through time. In an age of tumults and accelerating change, as the planet shifts under our feet and the heating air thickens with ash, we might well ask how long such a fable can last. Already the ground shifts, conditions become hard to predict. This year, as they say, may not be the brother of the next. 


\section{Acknowledgments}

The article is based on research supported by the Research Council of Norway (RCN) and the Estonian Research Agency (ETAG), most recently through the RCN-funded project "Dávggas: The Economic and Land-Use Conflicts of Sámi Reindeer Herding in Finnmark." I would like to thank the anonymous reviewers and editorial team of Valuation Studies for helpful and substantive engagements with the text.

\section{References}

Anderson, Benedict. 2006 [1983]. Imagined Communities. London: Verso.

Benjaminsen, Tor A., Hugo Reinert, Mikkel Nils Sara, and Espen Sjaastad. Forthcoming. "Misreading the Arctic Landscape." Norwegian Journal of Geography.

Benjaminsen, Tor A., Inger Marie Gaup Eira, and Mikkel Nils Sara, eds. Forthcoming. Samisk reindrift, norske myter. Trondheim: Fagbokforlaget.

Bjørklund, Ivar. 1991. "Samisk reindrift som pastoral tilpasningsform." In Forvaltning av vaire fellesressurser, edited by Nils C. Stenseth, Nina Trandem and Gørill Kristiansen, 181-188. Oslo: Ad Notam.

— , ed. 1999a. Norsk ressursforvaltning og samiske rettsforhold. Oslo: Ad Notam.

—. 1999b. "Den nasjonale integrasjon av det samiske reindriftssamfunn.” In Norsk Ressursforvaltning og Samiske Rettsforhold, edited by Ivar Bjørklund, 52-65. Oslo: Ad Notam.

- 2000. "Norges Ansvar." Dagbladet March 15.

- 2004. "Saami Pastoral Society in Northern Norway: The national Integration of an Indigenous Management System." In Cultivating Arctic Landscapes, edited by David Anderson and Mark Nuttall, 124-135. Oxford: Berghahn.

Bjørklund, Ivar, and Odd Brantenberg. 1981. Samisk reindrift-norske inngrep. Tromsø: Universitetsforlaget.

Bjørklund, Ivar, and Harald Eidheim. 1999. "Om reinmerker-Kulturelle sammenhenger og norsk jus i Sapmi.” In Norsk ressursforvaltning og samiske rettsforhold, edited by Ivar Bjørklund, 143-157. Oslo: Ad Notam.

Borgenvik, Erik Johan. 2014. "When You Think Like the State-The Political Ecology of Pastoral Modernization in Finnmark, Norway." Master's thesis, Norwegian University of Life Sciences.

Bourdieu, Pierre. 1994. "Rethinking the State: On the Genesis and Structure of the Bureaucratic Field." Sociological Theory 12 (1): 1-19.

Foucault, Michel. 2003. Society Must Be Defended. New York: Picador.

- 2007. Security, Territory, Population. New York: Palgrave Macmillan. 
2008. The Birth of Biopolitics. New York: Palgrave Macmillan.

Hansen, Thomas, and Finn Stepputat, eds. 2001. States of Imagination. London: Duke University Press.

Haraway, Donna. 1988. "Situated Knowledges: The Science Question in Feminism and the Privilege of Partial Perspective.” Feminist Studies 14 (3): 575-599.

Hausner, Vera, Per Fauchald, Torkild Tveraa, Elisabeth Pedersen, Johnny-Leo Jernsletten, Birgitte Ulvevadet, Rolf Ims, Nigel Yoccoz, and Kari Bråthen. 2011. “The Ghost of Development Past." Ecology and Society 16 (3): 4.

Haywood, Gordon, Johan Nilsson, Michael Franklin, Paul Gilbert, Linus Johansson Krafve, Lisa Linden, Mark MacGillivray, and Robert Meckin. 2014. "Valuation Studies: A Collaborative Valuation in Practice." Valuation Studies 2 (1): 71-85.

Hobart, Angela, and Bruce Kapferer. 2012. Contesting the State. Wantage: Sean Kingston Press.

Hobart, Mark. 1993. An Anthropological Critique of Development. London: Routledge.

Holand, Øystein. 2007. "Herd Composition and Slaughtering Strategy in Reindeer Husbandry-Revisited.” Rangifer 27 (3): 123-124.

Holbraad, Martin, and Morten Axel Pedersen. 2014. "The Politics of Ontology," Fieldsights-Cultural Anthropology Online January 13.

Johnsen, Kathrine Ivsett. 2014. "The Paradox of Reindeer Pasture Management in Finnmark, Norway." Online feature, Strategic Environmental Impact Assessment of Development of the Arctic. www.arcticinfo.eu/en/features/112-the-paradox-of-reindeer-pasturemanagement-in-finnmark-norway, accessed October 1, 2014.

—. Forthcoming. "Medbestemmelse, makt og mistillit i reindriftsforvaltningen." In Samisk reindrift, norske myter, edited by Tor Benjaminsen, Inger Marie Gaup Eira, and Mikkel Nils Sara. Oslo: Akademika.

Johnsen, Kathrine Ivsett, Tor Benjaminsen, and Inger Marie Gaup Eira. Forthcoming. "Seeing Like the State-Or Like Pastoralists? Conflicting Narratives on the Governance of Sámi Reindeer Husbandry in Finnmark, Norway." Norwegian Journal of Geography.

Kolers, Avery. 2000. "The Lockean Efficiency Argument and Aboriginal Land Rights.” Australasian Journal of Philosophy 78 (3): 391-404.

Lenvik, Dag. 1990. "Flokkstrukturering-Tiltak for lønnsom og ressurstilpasset reindrift." Rangifer 4: 21-35.

Lenvik, Dag, Ole Grannefjell, and Johannes Tamnes. 1982. "Kalvetap fra en ny synsvinkel.” Rangifer 2 (App 1): 62-74.

Li, Tania. 2007. The Will to Improve. London: Duke University Press.

LMD [Department of Agriculture and Food]. 2002. "Om dyrehold og dyrevelferd." Stortingsmelding Nr. 12 (2002-2003) www.regjeringen.no/ Rpub/STM/20022003/012/PDFS/STM200220030012000DDDPDFS.pdf 
2008a. "Kriterier/indikatorer på økologisk bærekraftig reintall.” www.regjeringen.no/upload/LMD/Vedlegg/Brosjyrer_veiledere_rapporter/ Rapport_okologisk_reintallskriterier.pdf

_. 2008b. "Veileder for fastsetting av økologisk bærekraftig reintall." www.regjeringen.no/upload/LMD/Vedlegg/Brosjyrer_veiledere_rapporter/ Veileder_fastsetting_okologisk_baerekraftig_reintall_des_2008.pdf

—. 2008c. "Høring: Rapport om kriterier/indikatorer for økologisk bærekraftig reindrift.” Høringsuttalelse Reinbeitedistrikt 16-Karasjok Vest. www.regjeringen.no/upload/LMD/Vedlegg/Horinger/ Okol_reindrift_012_Reinbeitedistrikt16.pdf

—. 2012. "Tale: Velkommen til Bords!” Archived speech. www.regjeringen.no/nb/dokumentarkiv/stoltenberg-ii/lmd/taler-ogartikler/2012/tale-velkommen-til-bords-1.html

Mathiesen, Svein, Bjørn Alfthan, Robert Corell, Ravdna Eira, Inger Marie Eira, Anna Degteva, Kathrine Johnsen, Anders Oskal, Marie Roué, Mikkel Nils Sara, Eli Ristin Skum, Ellen Inga Turi, and Johan Mathis Turi. 2013. "Strategies to enhance the resilience of Sami reindeer husbandry to rapid changes in the Arctic." In Arctic Council: Arctic Resilience Interim Report, 109-112. Stockholm: Stockholm Environment Institute and Stockholm Resilience Centre.

Oskal, Anders Isak. 1999. "Tradisjonelle vurderinger av livdyr." Rangifer Report 3: 121-124.

Oskal, Nils. 2000. "On Nature and Reindeer Luck.” Rangifer 20 (2-3): 175180.

2001. "Political Inclusion of the Sámi as Indigenous Peoples in Norway." International Journal of Minority and Group Rights 8: 235261.

Oskal, Nils, Ole-Henrik Magga, and Mikkel-Nils Sara. 2003. "Dyrevelferd i samisk kultur." Report to LMD, published with Samisk Høgskole. www.regjeringen.no/upload/kilde/ld/rap/2001/0017/ddd/pdfv/151133utredning_dyrevelferd_samisk.pdf

Paine, Robert. 1964. "Herding and Husbandry: Two Basic Distinctions in the Analysis of Reindeer Management." Folk 6 (1): 83-88.

— 1971. "Animals as Capital: Comparisons Among Northern Nomadic Herders and Hunters." Anthropological Quarterly 44 (3): 157-172.

— - ed. 1977. The White Arctic-Anthropological Essays on Tutelage and Ethnicity. Toronto: University of Toronto Press.

- 1992. "Social Construction of the 'Tragedy of the Commons' and Saami Reindeer Pastoralism.” Acta Borealia 2: 3-20.

1994. Herds of the Tundra. London: Smithsonian Institution Press.

. 2004. "Saami Reindeer Pastoralism: Quo vadis?" Ethnos 69 (1): 2342.

Porter, Theodore. 1995. Trust in Numbers. New Jersey: Princeton University Press. 


\section{Valuation Studies}

Reinert, Erik. 2006. "The Economics of Reindeer Herding: Saami Entrepreneurship Between Cyclical Sustainability and the Powers of State and Oligopolies.” British Food Journal 108 (7): 522-540.

Reinert, Erik, Iulie Aslaksen, Inger-Marie Gaup Eira, Svein Mathiesen, Hugo Reinert, and Ellen-Inga Turi. 2009. "Adapting to Climate Change in Reindeer Herding-The Nation-State as Problem and Solution." In Adapting to Climate Change, edited by W. Neil Adger, Irene Lorenzoni \& Karen O'Brien, 417-432. Cambridge: Cambridge University Press.

Reinert, Hugo. 2008. The Corral and the Slaughterhouse. PhD diss., University of Cambridge.

—. 2012a. "Knives for the Slaughter." Acta Borealia 29 (1): 35-55.

- 2012b. "The Disposable Surplus-Notes on Waste, Reindeer and Biopolitics." Laboratorium 4 (3): 67-83.

—. 2014. "Entanglements-Intimacy and Nonhuman Ethics." Society \& Animals 22 (1): 42-56.

Reinert, Hugo, Svein Mathiesen, and Erik Reinert. 2010. "Climate Change and Pastoral Flexibility." In Political Economy of Northern Regional Development, vol. 1, edited by Gorm Winther, 189-204. Copenhagen: Nordic Council of Ministers.

Sara, Mikkel-Nils. 2001. Reinen-Et Gode fra Vinden. Karasjok: Davvi Girji. Scott, James. 1998. Seeing like a State. London: Yale University Press.

Star, Susan Leigh, and James Griesemer. 1989. "Institutional Ecology, 'Translations' and Boundary Objects: Amateurs and Professionals in Berkeley's Museum of Vertebrate Zoology, 1907-39." Social Studies of Science 19 (3): 387-420.

Statens Reindriftsforvaltning. 2014. Ressursregnskap for reindriftsnoeringen. Alta: Statens Reindriftsforvaltning.

Stengers, Isabel, and Erik Bordeleau. 2011. "The Care of the Possible: Isabelle Stengers interviewed by Erik Bordeleau.” Scapegoat Iss. 1: 12-17, 27.

Strøm-Bull, Kirsti, Nils Oskal, and Mikkel Nils Sara. 2001. Reindriften $i$ Finnmark-Rettshistorie 1852-1960. Oslo: Cappelen.

Taussig, Michael. 1992. The Nervous System. London: Routledge.

Tyler, N., J. M. Turi, M. A. Sundset, K. Strøm Bull, M. N. Sara, E. Reinert, N. Oskal, C. Nelleman, J. McCarthy, S. Mathiesen, M. Martello, O. H. Magga, G. Hovelsrud, I. Hanssen-Bauer, N. I. Eira, I.-M. Gaup Eira, and R. Corell. 2007. "Saami Reindeer Pastoralism under Climate Change: Applying a Generalized Framework for Vulnerability Studies to a SubArctic Social-Ecological System." Global Environmental Change 17: 191206.

Vitebsky, Piers, and Anatoly Alekseyev. 2014. "What Is a Reindeer? Indigenous Perspectives from Northeast Siberia." Polar Record, first view article: $1-9$.

WCED (World Commission on Environment and Development). 1987. Our Common Future. Oxford University Press: Oxford. 
Hugo Reinert is a senior researcher at the Estonian Institute of Humanities, Tallinn University, and a research fellow at the Department of International Environment and Development Studies (Noragric), Norwegian University of Life Sciences. He has worked on a number of projects in the areas of environmental anthropology and geography, including studies of pastoralism, bird conservation and climate change policy. His current research examines the emergence of "sacrifice zones" in the context of the new Arctic mining boom. 